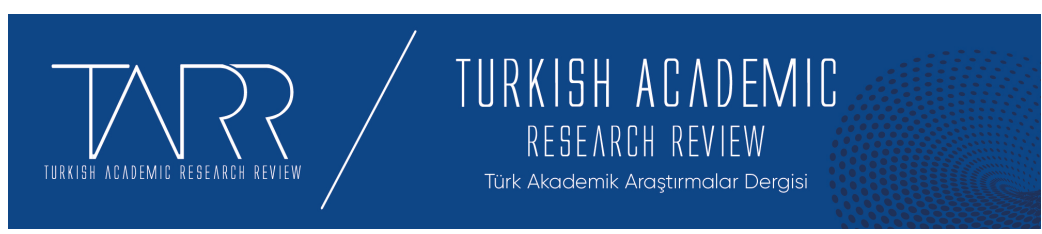

e-ISSN: 2602-2923 Yıl/Year: 2021 Cilt/Volume: 6 Sayı/Issue: 5

\title{
Daimî Varoluşsal Kaygı: İsmet Özel Şiiri Örneği
}

Permanent Existential Anxiety: The Case of Ismet Özel Poetry

\section{Rıfat ATAY - Bedirhan GÜVEN}

Prof. Dr., Akdeniz Üniversitesi İlahiyat Fakültesi, Felsefe ve Din Bilimleri Bölümü/ Prof. Dr., Akdeniz University, Faculty of Divinity, Department of Philosophy and Religious Sciences, rifatay@akdeniz.edu.tr, Orcid ID: https://orcid.org/0000-00018715-3023

Akdeniz Üniversitesi Sosyal Bilimler Enstitüsü / Akdeniz University, Social Science Institute, bedirhan.guvennn@gmail.com, ORCID ID: https//orcid.org/ 0000-00023039-3533

\begin{tabular}{r|l} 
Makale Bilgisi & Article Information \\
Makale Türü - Article Type & Araştırma Makalesi / Research Article \\
Geliş Tarihi - Date Received & 27 Ekim / October 2021 \\
Kabul Tarihi - Date Accepted & 28 Aralık / December 2021 \\
Yayın Tarihi - Date Published & 31 Aralık / December 2021 \\
Yayın Sezonu & Aralık \\
Pub Date Season & December
\end{tabular}

Atıf/Cite as: Atay, R. - Güven, B. (2021), Daimî Varoluşsal Kaygı: İsmet Özel Şiiri Örneği/ Permanent Existential Anxiety: The Case of Ismet Özel Poetry. Turkish Academic Research Review, 6 (5), 1517-1544. Retrieved from https://dergipark.org.tr/tr/pub/tarr/issue/67845/1015714

Intihal / Plagiarism: Bu makale, en az iki hakem tarafından incelenmiş ve intihal içermediği teyit edilmiştir. / This article has been reviewed by at least two referees and confirmed to include no plagiarism. https://dergipark.org.tr/tr/pub/tarr

Copyright (C) Published by Mehmet ŞAHIN Since 2016- Akdeniz University, Faculty of Theology, Antalya, 07058 Turkey. All rights reserved.

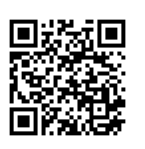

Turkish Academic Research Review - Türk Akademik Araştırmalar Dergisi 


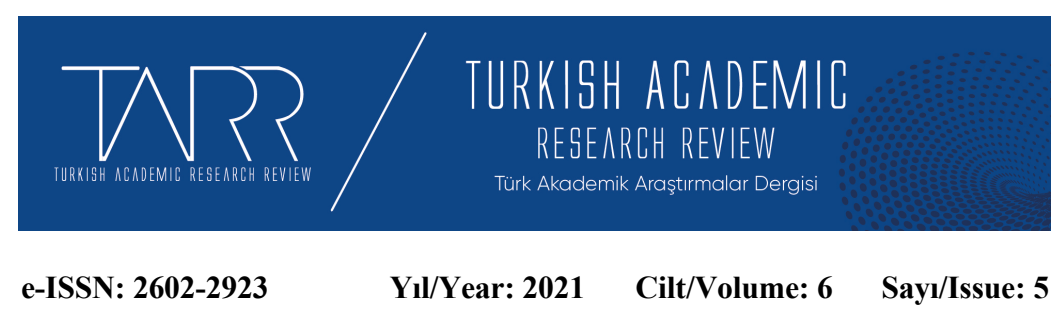

\title{
Daimî Varoluşsal Kaygı: İsmet Özel Şiiri Örneği
}

\author{
Rıfat ATAY - Bedirhan GÜVEN
}

\section{$\ddot{\mathbf{O z}}$}

Varoluşçuluğa göre epistemolojik açıdan bir kimsenin içinde bulunduğu dünyanın var oluşundan şüphe duymasının bir anlamı yoktur. Buna göre varoluşçuluk, her şeyden önce bireyin var oluşunu öne sürer ve öncelikle varoluşun bir varlık problemi olduğunu ifade eder. Bu bağlamda varoluşçu felsefe dinlerin ve klasik felsefenin öne sürdüğü gibi öz denilen şeyin var oluştan önce değil de varoluşun özden önce geldiği tezini savunur. Dolayısıyla bu anlayış gereği, bir kimse önce vardır ve sonrasında kendi bireysel özünü inşa eder. Bundan ötürü dünya ya da varlık, insanla olan ilişkisi içerisinde betimlenmek ve araştırılmak durumundadır. Bu noktada çalışmanın ana konusu olan "varoluşsal kaygı" sorunu ön plana çıkmaktadır. Kişinin kendini düşünerek dünyadaki varlığının doğası ile ilgilenmeye başlaması ve "Ben neyim?" diye sorması ile bu problem ortaya çıkmaktadır. İnsan zikredilen soru ile varoluşsal anlamda bir kaygının içerisine girdiğinde, yaşamında bir özne olarak kendisinin bilincine varır ve sorumluluğu üzerine alarak toplum/herkes ya da sosyal kimliğinden sıyrılma çabasıyla kendi kimliğini oluşturma yoluna girer.

Varoluşsal kaygı problemini, hayatını acı veren bir uyanma süreci olarak nitelendiren İsmet Özel örneği üzerinden ele almayı amaçlayan çalışmanın kapsamı Özel'in şiiri ile sınırlandırılmıştır. Din felsefesi alanının "insan-evren ilişkisi” ve "insan hürriyeti”" konuları zemininde ele alınan bu çalışma, literatür taramasından elde edilen verilerin dokümanter analiz yöntemine dayanmaktadır. Yapılan araştırmada Özel'in şiiri merkeze alınarak insanın "varoluşsal kaygı”sının aşamaları belirlenmiştir. Buna göre söz konusu evreler şu dört aşama olarak belirlenmiştir: Birincisi, insanın kendi mahiyeti ile ilgilenmeden önceki toplumsallaşmasından kaynaklı olarak "ben”i ile içerisinde bulunduğu dünyaya konumlanamama huzursuzluğu; ikincisi, bu huzursuzluğun sonucunda farkındalığın ortaya çıkmasıyla herkesleşmeme; üçüncüsü, herkesleşmemenin sonucu olarak ortaya çıkan yalnızlıktan sonra yeniden doğuş ile kazanılan kendilik bilinci; dördüncü ve sonuncu olarak da bitimsiz varoluşsal kaygı yolculuğudur.

Anahtar Kelimeler: Felsefe, İnsan, Varoluşçuluk, Varoluşsal Kayg1, İsmet Özel.

\section{Permanent Existential Anxiety: The Case of Ismet Özel Poetry}

\section{Abstract}

According to existentialism, epistemologically, it makes no sense for a person to doubt the existence of the world one lives in. Thus, existentialism asserts the existence of the individual first of all and states that existence is a problem of ontology. In this context, existential philosophy defends the thesis that what is called essence is not

Turkish Academic Research Review - Türk Akademik Araştırmalar Dergisi 
before existence, as religions and classical philosophy suggest, but existence comes before essence. Hence, in accordance with this understanding, one first exists and then builds one's own individual essence. Therefore, the world or existence has to be described and investigated in relation to human beings. At this point, the problem of "existential anxiety", which is the main subject of the study, comes to the fore. At this point, the problem of "existential anxiety", which is the main subject of the study, comes to the fore. This problem arises when a person begins to think about oneself and becomes interested in the nature of one's being in the world and asks "What am I?" When a person gets into an existential anxiety with the aforementioned question, one becomes conscious of oneself as a subject in one's life and takes the responsibility and tries to form one's own identity with an effort to get rid of society/everyone or social identity.

The scope of the study, which aims to deal with the problem of existential anxiety through the example of İsmet Özel, who describes his life as a painful awakening process, is limited to Özel's poetry. This study, which centers on the basis of the "human-universe relationship" and "human freedom" in the field of philosophy of religion, is based on the method of documentary analysis of the data obtained from the literature review. In the research conducted, the stages of human's "existential anxiety" were determined by focusing on Özel's poetry. Accordingly, the stages in question were determined as the following four stages: First, the uneasiness of not being able to position oneself in the world with the "I" due to the socialization of the human before one was interested in one's own nature; second, not becoming everyone with the emergence of awareness as a result of this restlessness; third, self-awareness gained through rebirth after loneliness as a result of not becoming everyone; the fourth and the last is the endless journey of existential anxiety.

Keywords: Philosophy, Human, Existentialism, Existential Anxiety, Ismet Özel.

\section{Structured Abstract}

The aim of the study is to deal with the problem of "existential anxiety" through the example of Ismet Özel's poetry. Özel describes his life as a painful awakening process in his autobiographical book Why Are You Not Here Waldo. This study, which focuses on the basis of the "human-universe relationship" and "human freedom" in the field of philosophy of religion, is based on the method of documentary analysis of the data obtained from the literature review. In the research conducted, the stages of human's "existential anxiety" were determined by concentrating on Özel's poetry.

The problem of "existential anxiety" arises when a person begins to think about oneself and becomes interested in the nature of one's being in the world and asks "What/who am I?" When a person gets into an existential anxiety with the aforementioned question, one becomes conscious of oneself as a subject in one's life and takes the responsibility and tries to form one's own identity with an effort to get rid of society/everyone or social identity. As far as existentialism is concerned, epistemologically, it makes no sense for a person to doubt the existence of the world one lives in. Hence, existentialism asserts the existence of the individual first and states that existence is a problem of ontology. In this context, existential philosophy defends the thesis that what is called essence is not before existence, as religions and classical philosophy suggest, but existence comes before essence. Therefore, in accordance with this understanding, one first exists and then builds one's own individual essence. Consequently, the world or existence has to be described and investigated in relation to human beings. 
When the problem of "existential anxiety" is handled through Özel's poems, it is understood that four stages similar to the existence phases determined by some philosophers such as Kierkegaard and Heidegger can also be seen in Özel's poetry. The first of these stages is the inability of one to position oneself in the world one lives in with one's "I" due to one's socialization before dealing with one's own nature. At this stage, the person has not yet been an individual and oneself, but has become identified with the society in which one lives. At this stage, according to Özel's thought, the individual who reflects on oneself exhibits a sceptical and curious stance towards what is presented with the sobriety of "hold on, and let's review". Because this is closely related to both the realization of "forcedness" in life and the emergence of our "humanity".

The second existential stage is "not becoming everyone" as a result of the awareness of the self, together with the uneasiness that occurs with the inability to be positioned in the world. At this stage, when the individual realizes one's own existence as an individual, one tries to get rid of the social identity that the herd or everyone imposes on one. The "loneliness" that makes itself felt in this situation, as in every person questioning one's existence, firstly emerges with the rejection of what is presented to one due to the search for "authenticity" as can be witnessed in the example of Özel. In this context, in view of Özel, one should stay away from the "shadow of silent stacks", who feel the comfort of being determined by avoiding the responsibility of making decisions about one's own existence as a result of "not becoming everyone".

The third existential stage is the self-consciousness gained by rebirth as a result of loneliness that emerges as a consequence of not becoming everyone. In this stage, the individual is no longer the "original man". According to Özel, at this stage, a person first defines oneself and changes one's understanding of oneself. In other words, the person now realizes oneself and becomes one's real self.

The fourth stage, which is called the permanent journey of existential anxiety, showed that the existential doubt of the individual who has reached self-consciousness will not come to an end and the search will last until the end of one's life. It is seen that Ozel's inner journey of self-discovery still continues even after he becomes a Muslim and secures his ontological existence. In this context, it can be said that the individual who has reached self-consciousness has to continue one's own search against the ongoing sociality by renewing one's daily life and the "bespoke life" that is the result of this situation. As Özel states, staying alive is possible by continuing the search within the self, because a person is alive as one searches and one understands as long as one keeps on searching. 


\section{Giriş}

Toplum ile girdiği ilişkide şekil alan ve yabancılaşan birey aynı zamanda toplum denilen şeyin nesnesi haline gelmektedir. İçinde bulunduğu hayatın gereklerine alışmayan/alışamayan insan, kendi iç dünyasına çekilip "bilmek” denilen girdabın içerisinde kendisini bulmaya ve inşâ etmeye başlamaktadır. Şiirlerinde

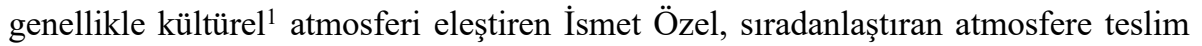
olarak sıradanlaşan bireyin karşısında olmuştur. Çarkın dişlerini tek tek bireylerden inşâ etmeye çalışıp insanın efendisi olan sistemde, Özel'in kendisini bulup özneleşme çabası, "birey"in kendiliğini önceleyen en ulvî tavır olmuştur.

Kişiyi kendi olmaklığından uzaklaştıran toplumsallaşma ve farkında olmadan içinde bulunulan herkesleşme, kendi ile hemhal olmuş birey tarafindan fark edilmekte ve böylelikle yalnızlaşma ortaya çıkmaktadır. Bunun sonucunda ise kişinin kendi ile olan yolculuğu başlamaktadır. Bireyin kendi varlığından yola çıkarak içinde bulunduğu atmosfere konumlanamaması var oluşun özünde bulunan "kaygı” dolayısıyladır.

Bu kaygı aslında çocukluktan başlayarak çoğu bireyin hayatı boyunca devam eden bir süreçtir, ki bu durum özellikle modern çağ insanı için daha doğrudur. Modern çağın bir bireyi, şairi ve düşünürü olan Özel'in şiir evrenine odaklanarak, bireyin içinde bulunduğu atmosfere konumlanamaması, yalnızlaşması, eğer mümkünse kazanacağı kendilik bilinci ve sonrasında ne zaman ve nasıl biteceği belli olmayan "sonsuz yolculuk" serüveni, işaretler çerçevesinde tespit edilmeye çalışılacaktır. Kendi serüvenini, "öncekilere benzemeyen, sonrakilerin benzemek istemediği bir merak çağının ortaya çıkardığı ve ortada bıraktığı bir insanım ben,"² cümlesiyle özetleyen Özel'in yolculuğunu kısmen tespit edilebilen belli aşamaları ile takibe başlamak yerinde olacaktır.

\section{Dünyaya Açılan Kapı/Çocuklukta Merak/Kaygı}

Aristoteles'in ifadesiyle, "bütün insanlar, doğal olarak bilmek isterler."3 İnsan istese de bu durumdan kendisini soyutlayamaz. Bilmek, merak etmeyi, merak etmek ise soru sormayı gerektirir ki bu doğal bir süreçtir. Bahsedilen duruma en iyi örnek, çocuklardaki merak, soru sorma ve bilme istediğidir. Bunun sonucunda sorular

\footnotetext{
${ }^{1}$ Ali Algül, Popüler Kültür ve Popüler Edebiyat, Europan Journal of Educational \& Social Sciences, Volume 4, Issue 2, October 2019, s. 145.

2 İsmet Özel, Waldo Sen Neden Burada Değilsin, Tiyo Yayınları, İstanbul 2018, s. 143.

3 Aristoteles, Metafizik, çev. Ahmet Arslan, Divan Kitap, İstanbul 2019, s. 107.
} 
ve kavrayışlar peş peşe gerçekleşir. Fakat zihin, içinde var olunan hayatın gerçeklerine alışınca, alışkanlıklar oluşunca, insan daha az sormaya ve merak etmeye başlar.

Yaşamı incelendiğinde içinde var olduğu hayata ben'i ile konumlanmaya çalışan Özel'e göre çocukluk, her haliyle en temiz ve doğal olanı karşılarken aynı zamanda "ilk karşı karşıya gelme”nin gerçekleştiği bir alandır. Çocukluk döneminde ortaya çıkan bu ilk karşı karşıya gelişin, hayatın diğer zamanlarında meydana gelebilecek karşılaşmalardan farklı bir yönü vardır. ${ }^{4}$ Zira "çocukluk" dünyanın ve içinde bulunduğu çağın yozlaşmasıyla karşı karşıya kalan benliğin ilk korunma yeridir. Çocukken ortaya çıkan olaylarla, nesnelerle ve kişilerle olan bu karşı karşıya geliş her şeyden önce "sahici”dir ve taklit edilemez. Bahsedilen durum, o karşılaşmayı bizzat tecrübe edene özeldir ve onun anlam dünyasında bir derinlik kazanabilir. ${ }^{5}$ Dolayısıyla "çocukluk"un, hayatını sürekli olarak "sahicilik/authenticity" gerçeklik arayışıyla irdeleyen şairin anlam dünyasında en önemli sığınak olduğunu söylemek mümkündür.

Hayatını acı veren bir uyanma süreci olarak nitelendiren Özel, yaşamını yüreğini burkan bir ayılma/ayıkma süreci olarak görmektedir. Bu hayatta "Ne kadar ayıktıysam o kadar keyfim kaçtı."7 diyen Özel'e göre, sahicilikten yoksun her bir insanın hayatı masallardan ibarettir. ${ }^{8}$ Masalların en kötüsü insanın kendisi hakkındaki masalıdır ve her insan "sahicilik" adına kendi masalını yıkmaya mecburdur. 9

Özel, kendi masalını şu şekilde anlatmaktadır:

Bir varmış bir yokmuş. Bir şair İsmet Özel varmış. İyi şiirler yazarmış. Nasıl olmuşsa bu İsmet bir gün komünist olmuş. Derken efendim, bir komünist olarak da iyi şiirler yazmayı başarmış ve hatta böylelikle yıldızı parlamış. Gel zaman git zaman, İsmet Özel'in duyguları, düşünceleri, inançları

4 Bahset Karslı, Farklılık ve Birlikte Yaşama: Göksun İlçesi Örnekliğinde Din ve Sosyal Bütünleşme, İlahiyat Yayınları, Ankara 2016, s. 104-122.

5 İbrahim Tüzer, İsmet Özel-Şiire Damitılmış Hayat, Dergâh Yayınları, İstanbul 2012, s. 155-156. Kişiliğinin şekillenmesinde neredeyse aynı süreçlerden geçen örnek bir şahsiyet olarak Aliya İzzetbegoviç üzerinden benzer bir tahlil için bkz.: Şeref Göküş, Bülent Koçoğlu, Rıfat Atay, “Aliya İzzetbegoviç’e Göre Bireyin ve Toplumun Eğitiminde Kadının Rolü”, Anmak, Anlamak ve Aşmak Bağlamında Aliya İzetbegoviç, ed. Yalçın Çetin, Nobel Akademik Yay., Ankara, 2021, s. 275331.

6 Kişinin kendi kendisine doğru, hakiki ve içten olması niteliği, kendi kendini aldatmaması durumu, insanlık durumumuzun özellikle de bir gün öleceğimiz gerçeğinin farkında olunarak, toplumun bizi belirlediği, her ne isek o yaptığ 1 tezine karşı, seçimlerin ve eylemlerin bütün sorumluluğunu üstlenerek geçirilen bir hayatın özelliği. Ahmet Cevizci, Felsefe Sözlüğ̈̈, Paradigma Yayınları, İstanbul 2000, s. 814.

7 Özel, Waldo, s. 111.

8 Özel, Waldo, s. 14.

9 Özel, Waldo, s. 14.

Turkish Academic Research Review - Türk Akademik Araştırmalar Dergisi 
değişmiş (masalın her varyasyonunda bu değişmenin sebepleri muhtelif) ve Müslümanlığı bir hayat yolu olarak benimsemiş. Ama işe bakın ki adam iyi şiirler yazmaya devam etmiş. Eh, o erdiyse muradına, biz de çıkabiliriz kerevetine. $^{10}$

Sahicilik, yapay olmayana yakınlık/özlem, Özel'in çocukluğuna dair izler taşıyan şiirlerinde dikkat çekmektedir. Küçükken Kastamonu'da oturduğu evlerinin dış kapısından,

Boyasıd1 tahta kap1

bu yanıla güvenirdim ona ${ }^{11}$ dizeleriyle bahseden Özel, çocukların/çocukluğunun masumiyeti/sahiciliği üzerinde durmaktadır. Masumluk doğallığın, doğallık ise gerçekliğin göstergesidir. Nitekim "boya" gerçekliğin/sahiciliğin üzerini kapatan ve öz ile ilgili olan her şeyi saklamaktadır. Aksine Çocukların evreni ise "boyasız", saf ve doğal/sahicidir. ${ }^{12}$

Çocukken karşılaşılan ilkler ile kendi anlam dünyasının nasıl şekillendiğini sonraları irdeleyen Özel, kendini iyice hissettiren sorgulama süreci sonunda kaçınılmaz olarak meydana gelen varoluşsal huzursuzluğu yaşamakta ve zihinsel dönüşümün izlerini ortaya koymaktadır. ${ }^{13}$ Ona kulak verilirse:

Sözlerimin anlamı beni ürkütüyor

böylesine hazırlıklı değilim daha.

Bilmek. Bu da ürkütüyor.

Gene de biliyorum ${ }^{14}$

Özel'in içinde var olduğu dünyayı anlamak ve içindekiler hakkında bilgi sahibi olmak için çocukluğundan bu yana ayrı bir gayret içerisinde olduğu anlaşılmaktadır. Zira çocukluk zamanlarına dair, "Benim dünyanın şekli hakkında yakınlarım dolayısıyla bir merak alanım vardı"15 diyen şair, "merak" hissinin kendi "ben"inde çok erken yaşlarda ortaya çıkması ve gelişmesiyle alakalı şunları söylemektedir; “Ben 6 kardeşin en küçüğüyüm. Küçük kardeş olunca öbürlerini gözlüyorsun. Büyükler küçüklerin ne yaptığını bilmez ama küçükler büyüklerin ne yaptığını bilir ve hep merak ederler. Ne yapıyorlar, nereye gidiyorlar. Hayat nasıl. Dünya nasıl bir şeydir? Bunları hep merak ederdim."16 Özel'in ifadelerinden de

10 Özel, Waldo, s. 15.

11 İsmet Özel, Of Not Being A Jew, Şule Yayınları, İstanbul 2005, s. 31.

12 Tüzer, Ísmet Özel, 162.

13 Tüzer, Issmet Özel, 172.

14 İsmet Özel, Erbain- Kırk Yılın Şiirleri, Tiyo Yayınları, İstanbul 2013, s. 172.

15 Tüzer, Ismet Özel, 211.

16 Tüzer, Ismet Özel, 24. 
anlaşılacağı üzere eğer birileri birilerini dikkate değer bir şekilde gözleyecekse, örnek alacaksa ya da birileri birilerinden bir şey öğrenecekse, bu her zaman hiyerarşik anlamda aşağıdan yukarı doğru olmaktadır. Aksine çocuklar kendi dünyalarında var olmaya başladıkları günden itibaren kendi kendilerine konuşarak oyun oynarken, ilk defa gördükleri bir böceği yerden alıp incelemeye koyulurken veya ilk defa bir elmayı tadarken ne hissettiklerine ve ne tepki verdiklerine gereken ehemmiyeti vermeyenlerse büyüklerdir. ${ }^{17}$

$\mathrm{Bu}$ bağlamda büyüklerin mükemmel olmadıklarını ancak sözlerini küçüklere/çocuklara geçirebildiğini dile getiren Özel, bunun sebebi olarak büyüklerin çocuklara karşı büyük olma imtiyazını kullandıklarını göstermektedir. Ona göre, çocukların büyüklere itaat etmesinin haklı bir sebebi olamaz. Çünkü onlar birçok şeyi doğru yapmıyorlar ve aynı şekilde birçok şeyi de bilmiyorlar. Hemen belirtmek gerekir ki büyüklere düşmanca tavır almanın da bir sebebi olamaz, zira çocuklara karşı yardımsever dostluk tutumunu sergileyenler yine onlar. Tam da bu noktada Özel'e göre, büyükler tarafından verilen desteğe karşı severek, içtenlikle hizmet etmek, ancak asla itaat etmemek, sonu itaate giden yardımı reddetmek ve insanların sahip oldukları yerin değerini bilmek/bildirmek gereklidir. ${ }^{18} \mathrm{Bu}$ tavır, Özel'in hiç kimseye minnet etmeden değer bilen "kadirşinas itaatsizlik" dediği davranış biçimini ortaya çıkarmıştır.

Özel'e göre "kadirşinas itaatsizlik" kendisinin otorite aleyhtarlığı ile ilgili bir şeydir; "Ben toplumun bana verdiği şeyin kadrini biliyorum, fakat bu bana verildi diye boyun eğmeye hiç niyetim yok. Ben ne itaat ederim ne de itaat ettiririm," düsturu ile yaşadığını ifade eden şair, İbrahim Tüzer ile yaptığı söyleşilerinde bu farikasının çocukluğundan gelen bir hususiyet olduğunu belirtmektedir. ${ }^{19}$ Ayrıca başkalarına özellikle de büyüklere bağlı-bağımlı olmadan bu hayatta kendi kendine var olarak hareket etme/ kendi kendine karar verme durumu için şu ifadeleri kullanmaktadır:

Gerçekle olan ilişkimi hiçbir zaman gerçeğin sınırları dolayısıyla kurmadım. Karar vermek, çocukluğumdan beri çok aslî bir şeydi. Algı ile çok bağlı saymadım kendimi. Kendimi bağlı saydığım şey karar idi. Bu karar da benim karar verdiğim şey olabiliyordu ancak. Bir de telkin edilmiş karar olabiliyor. İşte anneniz, babanız, ağabeyiniz, ablanız bir şeyi tercih ettiği için üzerinizde baskı yapabiliyor. Sevgiliniz, karını neyse yani. "O seviyor demek ki bunda

17 Çocukluk dönemi eğitimi hakkında geniş bilgi için bkz. Şeref Göküş, "II. Meşrutiyet Dönemi İslamcı Çizgideki Süreli Yayınlarda Aile ve Çocuk Eğitimi”, Artuklu Akademi, 7/1, (2020), ss.109-118.

18 Özel, Waldo, s. 20.

19 Tüzer, İsmet Özel, 35.

Turkish Academic Research Review - Türk Akademik Araştırmalar Dergisi https://dergipark.org.tr/tr/pub/tarr 
bir şey var" diyebilirsiniz. Ben de bu olmadı. Belki de biraz tersi oldu. Başkalarının tercihleri, "Dur bakalım bir de biz gözden geçirelim, elden geçirelim» şeklinde bir etki uyandırdı bende. ${ }^{20}$

"Dur bakalım bir de biz gözden geçirelim" ayıklığı, bilmek istemenin, sunulana karşı şüphenin ve merakın önkoşuludur. Ayrıca hayatın içinde hem "mecbur bırakılmışlık"ların fark edilmesi hem de "insanlığımızın" zuhur etmesiyle yakından ilgilidir. Ne zaman zor bir durumda kalsak, yalnız başımıza düşüne düşüne kavrayabileceğimiz, araştırmalar sonucu anlayabileceğimiz bir durum meydana gelse; birileri bahsedilen duruma dair ya kısa yoldan bir açıklama getirir, ya bazı kolay adlandırmalarda bulunur ya da kalkıp bize bir masal kurar. Biz bu masallara kulak verip kandığımız ölçüde insanlığımızı sıradanlaştırır ve insan olmanın özellikli vasıflarından uzaklaşırız. Özel'e göre, insanlığımızı yeniden elde etmemiz ve insan olarak kendimize gelmemiz sadece bizi uyutan bu türden masalların etkisinden sıyrılmakla başlar. ${ }^{21}$

Bu bağlamda şair, merak etmek ve bilmek istemek vasıflarını körelten, aynı zamanda çocukların kendi benliklerini keşfetmelerine engel olan "Allah'ın belaları büyükler"in, çocukların dünyalarına ait uçsuz bucaksız güzelliklerin farkına varmamalarını ve insanlıklarını elde edememelerini şöyle ifade etmektedir:

Büyükler o Allah'ın belaları

Anlasalardı bir ülkedir

Hem de ne çok şeyler için

Tedarikler ülkesidir çocukluk

Bekleyebilseydi büyükler karşılarına

Bir alan rengârenk çıkınca sürülmemiş hiç boya

Ses çıkarmadan şaşmayı öğrenebilselerdi

Bakmasalard kusura $^{22}$

Çocukken yoğun bir otorite karşııtı tavra sahip olduğunu ifade eden Özel, "büyüklerin küçükleri anlayamadıklarını" yaşamış olduğu bir hatırasıyla şu şekilde delillendirmektedir:

İlkokul 1. sınıfta bir öğretmen adayı staj dersi yaptı. Ders de resim dersiydi.

Bir Eskimo hikâyesi anlattı ve bu anlattığı hikâyeden bir sahneyi resmetmemizi istedi. Ben de hikâyede anlatıldığı gibi köpeklerin çektiği bir kızak resmi çizdim. Herhalde herkes öyle yapmıştır. Fakat benim resmimde,

Tüzer, İsmet Özel, 57.

Özel, Waldo, s. 13.

22 Özel, Of Not Being A Jew, s. 94. 
köpekler ikişerli durdukları için bir köpek görünüyor fakat altında dörtten fazla ayak var. Çünkü öbür köpeğin ayakları da görünüyor. Öğretmen sonunda güzel bulduğu resimleri topladı. İlkokulda küme şeklinde oturulurdu. Bizim kümedeki çocuklar "Öğretmenim, öğretmenim bu resim de güzel" diye benim resmimi işaret ettiler. O da geldi baktı ve "hayır" dedi. "Çok fazla ayak var."23 Antoine de Saint-Exupéry'nin "Küçük Prens”indeki "kocaman bir fili sindirmekte olan bir boa yılanı"24 örneğindeki gibi, dedim ki "Bu büyükler anlamıyorlar, öğretmen bunu göremedi". Bir köpek görünüyor ama dörtten fazla ayak var çünkü yanında öbür köpek var.”25

Nitekim bu "antikomformist / kadirşinas itaatsizlik tavrı", Özel'in kaleme almış olduğu hemen tüm eserlerinde düşünce dünyasının önemli bir anahtarını oluşturmaktadır:

Gençtim ya, ne farkeder deyip geçerdim nehrin uğultusu da olur, dalların hışırtısı da gözyaşı, çiğ tanesi, gizli dert veya verem ne fark eder demişim bilmeden farkı istemişim. ${ }^{26}$

Evet, ilmektir boynumdaki ama ben kimsenin kölesi değilim tarantula yazdılar diye göğsümdeki yaftaya tarantulaymış benim adım diyecek değilim tam düşecekken tutunduğum tuğlayı kendime rabb bellemeyeceğim razı değilim beni tanımayan tarihe beni sinesine sarmayan tabiattan riza dilenmeyeceğim. ${ }^{27}$

Görüleceği üzere Özel'in çocukluğundan bu yana ortaya koymuş olduğu meraklı ve sunulanlara karşı kaygılı "anti-konformist" davranış biçimi, toplumun/herkesin sunulanları kabule ve uymaya zorlandığı durumlarla ilişsilidir. Bunun yanında o, "kadirşinas itaatsizlik" tavrı ile kabul görmüş ya da egemen olan

Tüzer, İsmet Özel, s.27.

4 Antoine de Saint-Exupéry, Küçük Prens, çev. Ayberk Erkay, Lotus Yayınevi, Ankara 2005, s. 11.

25 Tüzer, Ísmet Özel, s.27.

26 İsmet Özel, Bir Yusuf Masal, Şûle Yayınları, İstanbul 2004, s. 8.

27 İsmet Özel, Çatllycak Kadar Aşkî, Adam Yayıncılık, İstanbul 2003, s. 31.

Turkish Academic Research Review - Türk Akademik Araştırmalar Dergisi https://dergipark.org.tr/tr/pub/tarr 
davranış modellerine uygun hareket etmeyerek içinde var olduğu hayatın ve kendisinin sahiciliğini/otantikliğini kaybetmemeye yani herkesleşmemeye çalışmıştır.

\section{Herkese Karşı Kaygı: Herkesleşmeme}

İnsanın, hayatın her evresinde vasat bir anlayış tutturarak basmakalıp formlar içinde tüketilen bir yaşamın karşısında olması kabul edilmeye zorlanılan mecbur bırakılmaların ayırdına varması ve bunların, öncelikle insanın kendi yaşamını tesir altına almaması için çaba göstermesi toplumsallaşmaya ${ }^{28}$ aykırıdır. Bu durum bireyin içinde yaşadığı toplumun/herkesin dışına atılmasına dolayısıyla yalnızlaşmasına sebep olmaktadır. Başka bir deyişle bireyin, toplumun standartları ve değer olarak nitelendirdiği her şeyi farkına bile varmadan içselleştirerek ve toplumsal görevleri yerine getirmeyi öğrenerek, toplumun bir mensubu haline gelme durumuna karşı çıkması/sorgulaması, kişinin tek başına kalması durumunu ortaya çıkarmaktadır.

Bahsedilen bu durum ile kendisini hissettiren "yalnızlık," var oluşunu sorgulayan her insanda olduğu gibi Özel örneğinde de ilk olarak herkes içinde olmasına rağmen "sahicilik" arayışı sebebiyle kendine sunulanın reddiyle birlikte ortaya çıkmaktadır. Söz konusu bu yalnızlık, insanlarla birlikte olamamanın sıkıntısıyla ortaya çıkan türden huzursuzluk değildir. Bu bağlamda Şair, kendisini çevreleyen "kalabalık" içerisinde yalnız olmayı, bilerek ve isteyerek yaşamaktadır, ki bu durum sahiciliği kovalayan her insanda ortaya çıkan bir bunalımdır. Özel, dünyayı kendi varlık alanı içerisinde anlamaya çalışıp yine dünyaya, toplumun/herkesin/ başkalarının hayatından devşirilen davranış ve tutumlar ile değil de kendi yapıp etmeleri ile karşıllk vermek istemiştir. ${ }^{29}$

"Herkesleşmeme" neticesinde şair, "bıktım tanımlanmaktan"30 diyerek "yalnız" kalmış; kendi varoluşuyla ilgili kararları alma sorumluluğundan kaçarak belirlenmiş olmanın kendilerine sağlamış olduğu rahatllğı yaşayan, Jean Baudrillard'ın ifadesiyle "Sessiz Yı̆̆ınların Gölgesi”nden ${ }^{31}$ uzak durmuştur. Burada sözü edilen yalnızlık, "ve ben gövdemi denkleştirmek için doğaya dineldim dineldim dineldim" 32 şeklinde otantik tarzda yaşanmak istenen ve "üzerime yüreğimden başka muska takmadan konuşmak istiyorum," ${ }^{33}$ şeklinde merkezine sahiciliğin konmasıyla

28 Ortega Y. Gasset, İnsan ve Herkes, çev. Neyire Gül Eşik, Metis Yayınları, İstanbul 1995, s. 196.

29 Tüzer, Ismet Özel, s. 229.

30 Özel, Erbain, s. 57.

31 Jean Baudrillard, Sessiz Yığınların Gölgesinde, çev. Oğuz Adanır, Doğu-Batı Yayınları, Ankara 2003, s.87.

32 Özel, Erbain, s. 73.

33 Özel, Erbain, s. 143. 
kalabalıklar içerisinde yaşanılan yalnızlıktır. ${ }^{34}$ Şair bu yalnızlığ getirmektedir:

saçlarıma bin küsur yalnızlı̆̆ı takıp girdiğim şehre

insan varlı̆ğmızdan tohumlar bıraksam

günü geçmiş bir gazete, toprak bir çanak

bir daha gelmem belki diye bir not bakır maşrapanın yanında ${ }^{35}$

Heidegger'e göre, herkes, gündelik hayatta birlikte olmanın aldığı genel bir formdur. Bu bağlamda herkes, "ne kendim olan ben'i, ne de karşımda duran şu teşhis edilebilir sen'i, ama bir nevi üçüncü olarak gayri şahsi o'yu, onun anonim bulunuşu"nu ifade etmektedir. ${ }^{36}$ Başkalarından/herkesten geri kalma, onları geride bırakma ya da onlar gibi olma kaygısı insan var oluşunu gündelik olma formunda belirlemekte ve onun davranışlarını güdülemekte ve/ya yönlendirmektedir. Herkesin, insan kendiliği üzerindeki bu gizli baskı ve iktidarı hayatın hemen her kesiminde hâkim bir olgudur. Heidegger, başkalarının/herkesin insan kendiliği üzerinde kurduğu bu iktidarı "herkes'in diktatörlüğü" olarak adlandırmaktadır. ${ }^{37} \mathrm{Bu}$ tespit, Özel'in dizelerindeki betimlemesiyle şöyle resmedilmiştir:

Başkalarının aşkıyla başlıyor hayatımız

yaprakla yağmurun aşkı mesela

kim olsa serpilen coşturuyor bizi

imreniyoruz başkalarının mahvına ${ }^{38}$

Bu bağlamda insan kendi'liği, başkaları/herkesin görünmeyen yönlendirmesi ve etkisi altında olduğundan, kendine gerçekten sahip değildir. Herkes/ başkaları, bireyin kendiliğinden var olmaklığını devralmıştır. Başkalarının keyfi, kişinin gündelik hayattaki varlık imkanları üzerinde buyurgandır. Dahası bu herkes/başkaları belirli başkaları değildir. Aksine, her bir başkası onları temsil ikame edebilir. Belirleyici olan şey ise gündelik ortamda göze çarpmadan elle tutulur bir şekilde olmadan ötekilerin/başkalarının birlikte olma anlamında insan kendiliğinden habersiz bir şekilde üstlendikleri egemenliktir. Dolayısıyla her bir kimsenin kendisi başkalarına/diğerlerine aittir ve onların gücünü arttırır. "Burada, 'kim' sorusuna karşıllk düşecek olan bu ya da şu [kimse] değildir; "kim", her bir kimsenin kendi ve

34 Tüzer, Ismet Özel, s. 234.

5 Özel, Erbain, s. 87.

36 Özkan Gözal, "Heidegger'de 'Herkes' Sorunsalı", Felsefe ve Sosyal Bilimler Dergisi, 30 (2020), s. 21.

37 Martin Heidegger, Varlık ve Zaman, çev. A. Yardımlı, İdea Yayınları, İstanbul, 2004, s. 189.

38 Özel, Çatllycak Kadar Aşkî, s. 22.

Turkish Academic Research Review - Türk Akademik Araştırmalar Dergisi 
kimileri olmadığı gibi, herkesin toplamı da değildir: Burada "kim" nötr olandır, herkes'tir." ${ }^{39}$

İşte insanın "ben"/“kendim" dediği şey, bir bakıma bütün bu gündelik işlerden ve ilişkilerden meydana gelmektedir. Gözal'ın Heidegger üzerinden yaptığ değerlendirmesine alıntılamak yerinde olacaktır:

Gerçekte, ben, gündelik hayat içerisinde herkes gibi ya da herkes olarak davrandığım ölçüde sahiden kendim değilimdir; herhangi biri benim yerimi doldurabilir, aynı şeyi bir başkası da benim yerime yapabilir çünkü. Gündelik hayatın gerçek öznesi herkes'tir ya da hiç kimse'dir bu bakımdan. ${ }^{40}$

"Ben ve sen gündelik hayatta biricikliğimiz ve sahiciliğimizle değil de herhangi biri olarak yani yeri başkalarıyla kolayca ikame edilebilir kimseler olarak "varız"dır." Özel'in ifadesiyle: "Başkalarının aşkıyla başlıyor hayatımız ve devam ediyor başkalarının hınçlarıyla" ${ }^{\prime 2} \mathrm{Bu}$ meyanda, kendiliğinin farkına varmadan yaşam süren kişi kendiliğinden yoksun bir şekilde, kendine yabancılaşarak, hayatını diğerlerinin rengine bürünmüş şekilde sürdürmek zorundadır.

Özellikle modern dönemde "şehir" tarafından ablukaya alınarak toplumsallaşmaya/ herkesleşmeye mecbur edilmiş birey, kendisi başta olmak üzere her şeye yabancılaşmaktan sıyrılamayıp "yaralı bilinç" halinde yaşamaya başlamaktadır. Bütün toplumsal aşamaların birer yabancılaşma süreci olarak düşünülmesi halinde insanın doğal karakterini değisştiren ve onu, tutkuları ve tatmin edilmemiş arzularıyla yaşayan yabancılaşmış bir varlık haline getiren nedenin bizzat toplum/herkes olduğu gerçeğini ortaya çıkmaktadır. ${ }^{43} \mathrm{Bu}$ bağlamda "toplum, topluluk, koskoca bir ruhsuzluktur;" dolayısıyla topluluğun/ "doğalaşmış, mekanikleşmiş, neredeyse mineralleşmiş insanlık" atmosferinde birey, "insanlık”tan çok "insanlık dışı ortam" içinde yaşamını sürdürmektedir. ${ }^{44}$ Böyle bir ortamda yaşayan insanı, Özel şöyle betimlemektedir:

Gizemli bir dehliz gibi şehri dolaşıyorum

sıkıca tutuyorum kendimi şehre karışmaktan alıkoymaya

her yerimde urlar çıkıyor, biraz kürt, biraz köylü, biraz makina

kangren oluyorum bahar geldiği için

39 Heidegger, Varlık ve Zaman, s. 189; Gözal, “Heidegger'de 'Herkes' Sorunsalı”, s. 23.

40 Gözal, "Heidegger'de 'Herkes' Sorunsalı", s. 21.

${ }^{41}$ Gözal, "Heidegger'de 'Herkes' Sorunsalı", s. 21.

42 Özel, Çatlyycak Kadar Aşkî, s. 23.

43 Daryush Shayegan, Yaralı Bilinç- Geleneksel Toplumlarda Kültürel Şizofreni, çev. Haldun Bayrı, Metis Yayınları, İstanbul 1991, s. 43.

44 Gasset, Insan ve Herkes, s. 29. 
urlarımı kesiyorum kör bir usturayla

ama kopmuyor onlar ve bana şehri dolaştırıyor. ${ }^{45}$

Gündelik hayatın ontolojisini anlamada Will Durant'ın, "Sürekli olarak neyle uğraşıyorsak oyuzdur." ${ }^{46}$ sözüne başvurulduğunda "sıradanlık, çeşitlilik göstermeyen, alışılagelmiş düzen içinde yapılan" anlamında rutin ${ }^{47}$ kavramıyla karşılaşılacaktır. Dolayısıyla insanlar bir bakıma, gündelik işler ve ilişkiler münasebetiyle rutin olarak yaptıkları her ne ise o olmak durumundadır. Toplumsallaşma ile birlikte insanlar, herkesin içinde, herkesin yaptı̆̆ını, herkes gibi yapmaktadır. Hâliyle kapılıış olunan bu rutin içinde insan, kendi kendiliğini / biricikliğini yaşamaktan öte bir biçimde herhangi biridir. ${ }^{48}$

İnsanın, benliğiyle/kendiliğiyle olan münasebetini yitirerek herkesin etkisi altına girmesi ve gerçek benliğiyle olan içsel bağlantısını keserek yabancılaşması erken dönem şiirlerinden birinde Özel tarafından şöyle ortaya konulmaktadır:

Köleler gördüm, karavaşlar

hayaları burulmuş bir adamın ayaklarını yıkamaktalardı artık kelimeleri kalmamış fiyatları sormaktan

saçları taranılmaktan usanmışlar

sinemalarda saklanıyor kışın

yaz olunca denizin yalayışlarına

kaldırımlarda demokrat

otobüslerde dindar

geceyi

saatlerine bakarak anlıyorlar

ve sabah

gökyüzünün karnını gerdiği zaman

dağların kokusundan fabrikalar

acıkınca

Köleler!

gözleri camekânlarda ${ }^{49}$

Gözleri vitrinlerde olan ve kendi benliğine yabancılaşarak yaşayan modern insanın, toplumun/ herkesin önüne koyduğunu izlemekten başka şansı yoktur.

45 Özel, Erbain, s. 88.

46 Will Durant, Felsefenin Öyküsü, çev. Ender Gürol, İzdüşüm Yayınları, İstanbul 1997, s.61.

47 TDK., (Erişim Tarihi: 10 Ekim.2021)

48 Gözal, "Heidegger'de 'Herkes' Sorunsalı", s. 19.

49 Özel, Erbain, s. 164.

Turkish Academic Research Review - Türk Akademik Araştırmalar Dergisi https://dergipark.org.tr/tr/pub/tarr 
Dolayısıyla kendisine sunulana mecbur birakılan insan "her an kendi kendisi olmaktan çıkmak, biricik ve aktarılması olanaksız benliğini yitirmek" tehlikesiyle karşı karşıyadır. ${ }^{50}$

Özel, 1964 yılının başından itibaren kaleme aldığı şiirlerinde "herkes"lerin ve herkesin içinde yaşadığı "şehrin" alçak bir tonda da olsa eleştirisini yapmaya başlamıştır. Bu dönemde şair ne türden yozlaşmaların karşısında olduğunu görüp kendine olan güvenini açıkça ortaya koyan bir tavır içerisine girmiştir. ${ }^{51}$

Böylelikle "aklını yorgun düşürmemek" için gözlerini camekanlardan sunulanlara diken köleler/herkesler, kendi kendiliğine dönüp "benliğe dalma" korkusundan kurtulmak için "vitrinin göbeğinde" bulunmak telaşına düşmüşlerdir. ${ }^{52}$

Çünkü aklını yorgun düşürmeyen her insan

İçerisinde

Bir gün soğuk ve rutubetli ve gözün

Gözü görmediği mahzenlere düşmek

Oralarda çürümek korkusu taşır

Korkudan kurtulmanın yolu

Ben size söyleyeyim

Vitrinde

Mümkünse vitrinin göbeğinde

Kendine bir yer beğenmekten geçiyor

Gözde değilse göz önünde o da olmadı göz altında ${ }^{53}$

Özel, "herkes"in bu tutumunu, "olduğundan fazla sanılmak" olarak nitelendirmektedir. Çünkü kendiliğine yönelen ve etrafinda olup biten her şeyin "oluş"u üzerine mülahazalarda bulunup onlara mütehakkim olma olasıllğını düşünmeye başlayan ve "benliğine dalan insan" gerçek anlamda bir zahmet içindedir. Bahsedilen durum herkesin/toplumun/modern insanın amaçladığı bir şey değildir. Zira o, biteviye "göz önünde" olanla ve "göz önünde" olmayı öncelediği için, "mış gibi” eyleyerek mânâdan yoksun bıraktığı hayatının hakikatinin anlaşılmasını istemez. Dolayısıyla modern insan, hep görünüşle ilgilenir ve "hariç"te olma halini yaşar. "İç", ile hemhal olma durumu modern insanın/ "herkes"lerin yaşam formunun çok dışında kalmaktadır. ${ }^{54}$

50 Gasset, Insan ve Herkes, s. 45.; Tüzer, İsmet Özel, s. 286.

51 Tüzer, İsmet Özel, s. 168.

52 Tüzer, İsmet Özel, s. 287.

3 Özel, Of Not Being A Jew, s. 68.

54 Tüzer, İsmet Özel, s. 287. 
Bu bağlamda şairin sorduğu şu soru oldukça manidardır:

söyleyin

aynada iskeletini

görmeye kadar varan kaç

kaç kişi var şunun şurasında? ${ }^{55}$

"İç" ile hemhal olan kendiliğine yönelmeye başlayan "ben", "herkes"in arasından çıkıp gitmek ister. Fakat "ben”in bu çıkıp gitme eylemi, Özel'in tespitine göre, anlık bir düşünüşün sonucunda gerçekleşmemektedir:

gördüm

gözlerinde zındanlarla bana baktıklarını

düşündüm yaslanarak şehrin kasıklarına

düşündüm kafa kemiklerimi eritinceye $\operatorname{kadar}^{56}$

Kafa kemiğini eritene kadar düşünmek; hayatını başkaları/herkesten ödünç alanların değil "kendi kendine var olma"klığının sorumluluğunu alanların, tanımlanmaktan bıkanların, mangalara girmeyenlerin harcıdır. Bu bağlamda Özel'in, dünya karşısında sıradanlaşan başkaları/herkesten ziyade, hem kendisi hem de varlık sahasında yer edenlerin “oluş”u üzerine düşünüşü dikkat çekicidir. Özel'in dizeleri bu çaresiz savruluşları çok çarpıcı bir şekilde resmederek modern insanın dramını ortaya koymaktadır:

Başkalarının aşkıyla başlıyor hayatımız

ve devam ediyor başkalarının hınçlarıyla

düşmanı gösteriyorlar, ona saldırıyoruz

siz gidin artık

düşman dağıldı dedikleri bir anda

anlaş1lıyor

baştan beri bütün yenik düşenlerle

aynı kışlaktaymışız

incecik yas dumanı herkese ulaşıyor

sevinç günlerine hürya doluştuğumuzda

tek başınayız.

Diyorum hepimizin bir gizli adı olsa gerek

belki çocuk ve ihtiyar, belki kadın ve erkek hepimiz, her birimiz gizli bir isimle adaşız

55 Özel, Erbain, s. 235.

56 Özel, Erbain, s. 164

Turkish Academic Research Review - Türk Akademik Araştırmalar Dergisi https://dergipark.org.tr/tr/pub/tarr 
yoksa şimdiye kadar hesapların tutması lâzımdı

hayatımıza kendi adımızla başlardık

bilmediğimiz bu isim, hesaptaki bu açık

belki dilimi çözer, aşkımı başlatırım

aşk yazılmamış olsa bile adımın üzerine

adımı aşkın üstüne kendim yazarım. ${ }^{57}$

Özel, "aşk”ım dediği, kendi var olmaklığını inşa etmeye çalışıı̆ı hayatını, kendisi başlatmak istemektedir. Zira hayatını başkalarından "ödünç alma" durumu yenik düşmek anlamına gelmektedir. $\mathrm{O}$, aynı zamanda dünya karşısında kendi benliğinin almış olduğu yeri de inşâ etmektedir. Toplumsallaşmanın ortasında kendi deyimiyle "mangalar" a girmemekte ve kendi hayatını/aşkını başlatmak istemektedir.

\section{Varoluşsal Kaygı İçinde Kazanılan "Kendilik"}

Michel Foucault'un "kendini bilmek" bağlamında önemli kazanımlar elde eden kimseler için dediği gibi Özel, "başlangıçtaki insan" değildir artık. ${ }^{58}$ Gündelik çalışmalarını ve yaşamını, sürekli varoluşsal kaygı ve sahicilik arayışının yardımıyla, ilk baştaki insan olmamak için dengeleyebilmiştir. ${ }^{59}$

Burada dikkate değer bir durum, "Amentü” şiiriyle Müslüman görüşüne bağlandığını bildiren şairin, Müslümanlığın esasını oluşturan "kadir-i mutlak" Tanrı inancıyla ontolojik çıkmazlarına cevap bulmuş olması; başka bir deyişle hayatının çok erken yıllarından başlayarak kendini hissettiren otantik duruşunun doğal sonucu olarak "yeniden doğuş"u gerçekleştirmiş olmasıdır. ${ }^{60}$ Şiirde bunu takip etmek mümkündür:

İnsan

eşref-i mahlûkattır derdi babam

bu sözün sözler içinde bir yeri vardı

ama bir eylül günü bilek damarlarımı kestiğim zaman

bu söz asıl anlamını kavradı

...

bu söz yüreğime kadar alçaldı

damar kesildi, kandır akacak

57 Özel, Çatlyycak Kadar Aşkî, s. 23.

58 Michel Foucault vd., Kendini Bilmek, çev. Gül Çağalı Güven, Om Yayınevi, İstanbul 2001, s. 2 .

59 Tüzer, İsmet Özel, s. 241-242.

60 Tüzer, İsmet Özel, s. 242. 
ama kan kesilince damardan sıcak

sımsıcak kelimeler boşandı

aşk için karnıma ve göğsüme

ölüm için yüreğime sürdüğüm eczâ uçtu birden

aşk ve ölüm bana yeniden

su ve ateş ve toprak

yeniden yorumland $1^{61}$

Hayat

dört şeyle kaimdir, derdi babam

su ve ateş ve toprak.

Ve rüzgâr.

ona kendimi sonradan ben ekledim

...

eşref-i mahlûkat

nedir bildim. ${ }^{62}$

Çoğu kişi gibi Özel'in de "insan var olanların en şereflisidir" umdesinin anlamını "idrak" etmesi pek kolay olmamıştır. Toplumsal norm ve koşullar, ayrıca şairin çevresinde bulunan insanlarla olan ilişkisi, onu "kendine kıyma psikozu" içerisine sokmuştur; özellikle bahsedilen ortamlardaki yabancılaşma ve insanların kimliksizleşerek yaşayıp gitmeleri, "varlığının dünya içerisinde durduğu yeri sorgulayan Özel'i ‘bir eylül günü bilek damarları'nı kesmeye yöneltmiştir.”63

Hemen belirtmek gerekir ki Özel'in "Müslüman" olmasılyla sonlanan durum mutlak emniyet alanına yönelik kaygılardır. Bahsedilen bu emniyeti elde etmiş olan Özel, rehavet içerisinde olmadığından "Müslüman" dünyanın içerisinde var olan yabancılaşmayı da kısa sürede fark etmiştir. Var olan bu durumun yıpratıcılığından kendini uzak tutmak için dünya karşısındaki otantik duruşunu devam ettirmiştir ve "yeniden doğuş"u, yaşam, herkes ve modern dünya karşısındaki duruşu sebebiyle tavrında herhangi bir "değişme" meydana gelmemiştir. ${ }^{64}$

Şair, "Yaşamak Umrumdadır" ve "Sevgilim Hayat" şiirlerinde kendi varlık alanında yapıp etmelerini merkeze koyarak coşkuyla bağlandığı hayatı bir "sevgili" olarak algılamaktadır:

61 Özel, Erbain, s. 177.

62 Özel, Erbain, s. 184

63 Tüzer, Ismet Özel, s. 252.

64 Tüzer, İsmet Özel, s. 242.

Turkish Academic Research Review - Türk Akademik Araştırmalar Dergisi https://dergipark.org.tr/tr/pub/tarr 
Ben

Topraktan siyriliyorum

$\cdots$

Ben atlara ve uzaklara hayrandım ${ }^{65}$

Yaşamak debelenir içimde kıvrak ve küheylan

Beni artık ne sıkıntı ne rahatlık haylamaz

Yürüsem rahmet boșanacak ${ }^{66}$

Sana bir karşıllık vereceğim

Toprağı deşen boğuk sesimle

Sana bir karşıllık vereceğim

amansız kum firtınası altında

Sana bir karşıllk vereceğim

Birbiri üstüne yığılırken günler

Ey taşan suların imkânı

Ey suların bekâreti sana

Bir karşılık vereceğim ${ }^{67}$

Şair, kendi beni'nin dinginlik bulabileceği bir hayata hariçten yapılan müdahaleleri "iftira" olarak değerlendirmektedir. Bu duruma karşıllk verme gayreti içerisinde olmuştur. Özel'in alışılagelmişlik karşısında ayık olma halinin devamıyla birlikte "yeniden doğuş”a giden yolda önemli bir kazanım olarak beliren bu gayreti, "Sevgilime İftira" şiirinde dikkat çekmektedir: ${ }^{68}$

sözlerimi etime bastırıyorum

$\cdots$

yeter ki

sağlam senetler verilmiş sanılırken aşkı karartmak için

sen bir daha beni saçlarınla sıyır

onların mühürlerini kımıldatan barut dumanlarını

65 Özel, Erbain, s. 102.

66 Özel, Erbain, s. 103.

67 Özel, Erbain, s. 104.

68 Tüzer, İsmet Özel, s. 244. 
solumaktan biraz çopurlanmıştır sesim. ${ }^{69}$

$\cdots$

o zaman

senin çardağına çıkarken

karıştırırken şarapla kendimi sana

varsın gün geçtikçe herşeyde biraz kahır

biraz bakır çalığı olsun lokmamızda

bana soru sor artık

beni kurtarma, konuştur

beni yaz geceleri patlayan sağnaklara bağışla. ${ }^{70}$

Var olmayı tasarlayarak "herkesleşmek"ten bertaraf olmanın bir diğer göstergesi de kişinin yaşadıklarından sorumlu olmasıdır. İçsel dönüşümü gerçekleştirmenin bu önemli aşamasında kişi, bireyselleşmenin sınırlarına yaklaşmaktadır ve aynı zamanda Carl G. Jung'un ifade ettiği gibi, “tüm insanlığın ortak bilincine bir sunuda ve katkıda bulunmuş olmaktadır." ${ }^{71}$ Bizce, Özel bunu felsefe ve şiir ile yapmıştır. Örnek vermek gerekirse:

“Üstümde yıldızlı gök” demişti Königsberg’li

"içerimde ahlâk yasası".

Yasa mı? Kimin için? Neyi berkitir yasa?

İster gözünü oğuştur, istersen tetiği çek

idam mangasındasın içinde yasa varsa.

Girmem, girmedim mangalara

Yer etmedi adalet duygusu

içimde benim

çünkü ben

Ömrümce adle boyun eğdim.

Yıldızlı gökten bana soracak olursanız

Kösnüdüm ona karş1

Onu hep altımda istedim. ${ }^{72}$

Şiirde geçen “Üstümde yıldızlı gök”, "içerimde ahlak yasası" Kant'ın (1724-1804) şu cümlesinden ödünç alınmıştır:

69 Özel, Erbain, s. 152-153.

70 Özel, Erbain, s. 152-153.

71 Carl Gustav Jung, Dört Arketip, çev. Zehra Aksu Yılmazer, Metis Yayınları, İstanbul 2003, s.13.; Tüzer, İsmet Özel, s. 245.

72 Özel, Çatllycak Kadar Aşkî, s. 22-23.

Turkish Academic Research Review - Türk Akademik Araştırmalar Dergisi https://dergipark.org.tr/tr/pub/tarr 
İki şey, üzerlerine sık sık eğilip ısrarla düşünülürse, insanın ruhsal yapısını hep yeni, hep artan bir hayranlık ve korkunç saygiyla dolduruyor: Üzerimdeki yıldızlı gök ve içimdeki ahlâk yasası. Her ikisini, karanlıklarda gizlenmiş ya da benim ufkumun ötesinde aşkın alanda imişlercesine aramama ve sırf tahmin etmeme gerek yok; onları önümde görüyorum ve doğrudan doğruya benim kendi varoluşumun bilincine bağliyorum. ${ }^{73}$

Görüldüğü üzere Özel, Kant’’n doğduğu yerin ismini verip fillozofa ait görüşleri zikrettikten sonra konuya dair kendi düşüncelerini sıralayıp şiirinde anlam genişlemesine olanak sağlamıştır.

Şair, yeniden doğuşuna delalet eden bir başka şiirinde, hayatını, aşklarını, inançlarını ve arkadaşlarını sorgulamaktadır, yaşanmışlıkların acısını dindirmek için varmak istediği ferahlı̆̆ı, yıllar öncesinde anlamayı denediği kitabın fakat başaramadığı sayfalarına tekrar dönerek işaret eder. Özel'deki bu yönelim, herhangi bir çaresizliğin göstergesi olarak değil de, hayatın içerisinde bütünüyle yer almış ben'in sahici olanın arayışını daha fazla istemesi şeklinde anlamak daha doğru olacaktır. ${ }^{74}$ Şu dizeler bu anlamayı teyit eder gibidir:

Karanlık sözler yazıyorum hayatım hakkında.

Aşklarım, inançlarım işgal altındadır

tabutumun üstünde zar atıyorlar

cebimdeki adreslerden umut kalmamıştır

toprağa sokulduğum zaman çapa vuran adamlar

denize yaklaşınca kumlar ve çakıl taşları

geçmiş günlerimi aşağılamaktadır ${ }^{75}$

Karanlık sözler yazıyorum hayatım hakkında

öyle yoruldum ki yoruldum dünyayı tanımaktan

saçlarım çok yoruldu gençlik uykularımda

acılar çekebilecek yaşa geldiğim zaman

acıyla uğraşacak yerlerimi yok ettim.

Ve şimdi birçok sayfasını atlayarak bitirdiğim kitabın

başından başlayabilirim. ${ }^{76}$

73 Immanuel Kant, Pratik Aklın Eleştirisi, çev. Gertrude Durusoy, Türkiye Felese Kurumu, Ankara 1999, s. 174.

74 Tüzer, Issmet Özel, s. 246.

75 Özel, Erbain, s. 159.

76 Özel, Erbain, s. 160. 
Özel'e göre beşer kıyafetinde yaratılan ve dünyadaki ömrünü tüketen herkes kendini bilme durumuna kavuşmaz. Bu bağlamda hayat sahibi olmak imkân taşımak demektir. İnsanların imkân taşıması demek; o güne kadar ne iseler oldukları şeyin ötesine geçebilme, üstüne çıkabilme gücüdür. Dolayısıyla insan hayatı kendi kendini tekrar eden bir “devr-i alem” olmadığı takdirde, gerçekten insan hayatı olur. ${ }^{77} \mathrm{O}$ bunu, "Her kim ki bizzat kendi hayatının manasını" de değişme uğratmaya müsait veriler üretmekten geri durmaz; işte biz ona yaşayan insan deriz," "79 şeklinde ifade etmektedir.

“Çözülmüş Bir Sırrın Üzüntüsü”nde ise Özel, öncelikle gündelik kazanımlarla ve kitle psikolojisiyle içi boşaltılarak anlamsız hale getirilen eski yaşanmışlıkların neticesinde eline geçenlerin neler olduğuna işaret etmektedir:

Yaşamaktan öte özür bulamayınca aşka

sonuçları bir bir gözden geçiriyorum

pulluklarla devrilen toprağın 1slaklığındaki can

madenlerin buharından elde edilen büyü

bazı yasak kitapların verdiği dinç duygular

nelerse ki yaşamak sözünü asi kılan

nelerse ki lekesiz, umutlu ve budala. ${ }^{80}$

Her bir "fark etmek" eylemi, ona göre, bir dönüm noktasıdır. Bu bağlamda her bir dönüm noktası aranılan "hakikat"in bir parçasıdır. Hakikatin var olacağı ortamı tesis etme zamanı, şimdiki zamandır. ${ }^{81}$

İnsanın

gölgesiyle tanımlandığı bir çağda

marşlara düşer belki birkaç şey açıklamak

belki ruhların gölgesi

düşer de marşlara

mümkün olur babamı

varlık sancısıyla çağırmak ${ }^{82}$

“Gölgesiyle tanımlanan” bir insan, artık kendi ışığını kesmekte ve gölgesi tarafından ele geçirilmektedir. Jung, bu tehlikeyi yaşayan insanların, her firsatta başkası üzerinde olumsuz bir etki bırakmayı tercih ettiklerini ve çoğu zaman şanssız kişi konumunda

77 Özel, Waldo, s. 133.

78 Özel bu kaygısını bir kitap başlığı yaparak kitlelerin bu konuda daha çok dikkatini çekmek istemiş gibidir: İsmet Özel, Hayatın Mânâsı versus Mânâlı Bir Hayat, haz., Ercan Yıldırım, Şule Yay., İstanbul, 2010.

79 Özel, Waldo, s. 136.

80 Özel, Erbain, s. 171.

81 Özel, Waldo, s. 183.

82 Özel, Erbain, s. 181.

Turkish Academic Research Review - Türk Akademik Araştırmalar Dergisi 
olduklarını ifade etmektedir. ${ }^{83}$ Çünkü bahsedilen insan tiplemesi başkaları/herkes tarafından "marşlar"la kontrol edildikleri için "kendilik" düzeyi altında yaşamakta ve kalabalık psikolojisiyle hareket etmektedirler. ${ }^{84}$ Yine Özel'e kulak verilirse:

İnsan yeryüzündeki uyanışına yaratılmış olduğunu fark ederek varır. Fakat iş burada bitmez. Aksine burada başlar. Çünkü yaratılmış olmayı kavramak aynı zamanda kişinin noksanını bilmesi demektir. Bu da bir arayışı gerektirir. Nedir noksan? Nasıl, neyle giderilir? Kaybolduğunu hissettiğimiz ister bir heybe olsun, isterse deve, arayış başlamıştır; büyük arayış. ${ }^{85}$

Şair'in burada belirttiği “arayış” durumu günümüzde çoğu modern insanın problemlerinin dillendirilmesinden başka bir şey değildir. Örneğin, varoluş sancıları çeken bir arkadaşımın yorumu tam da bu tespitin ifadesi gibidir: "Ben mesela bir ömür harcanıp yine de tamamlanamayacak olmanın, neden yaratıldığını bir türlü anlamayacak olmanın insan için herhalde en büyük eksiklik olabileceğini düşünüyorum. Anlayamıyoruz... bilmiyoruz. Aşırı köşeye sıkışmışlık hissi veriyor bu bana." 86

Hususiyetle vurgulamak gerekir ki Özel, Müslüman olduktan sonra da “anlam”dan yoksun bir yaşam sürdürmekten her daim uzak durmaya çalışmıştır. Söz konusu bu çaba içerisinde olan kimseler "benliğin asıl gerçekliğe uyanması" için kendi varlık sahalarında harekete devam eder ve olabilecek körelme noktalarından kaçınırlar. ${ }^{87}$

Her bir insanın kendisi hakkındaki kavrayışı, onun iradî bağlamda yapıp etmelerine şekil veren temel etkendir. İnsan kendisini nasıl kabul ediyorsa hareketlerini de ona göre şekillendirmektedir. ${ }^{88}$ "Bilmek sorumluluk taşımaktır. Yükümlülük, bilenlerin payına düsser." ${ }^{\text {89 }}$ diyen Özel'e göre bazı görevleri yüklenebilmek, o görevleri yüklenmeye değdiğini anladıktan sonra mümkündür. Bu bağlamda insan, her şeyden önce kendisini tanımlamakta, "daha doğrusu getirilmiş tanımlardan birini benimsemekte;" böylece mezkur tanımın gereği ne ise ona göre davranmaktadır. Dolayısıyla bireyin davranışlarındaki değişiklik, onun kendi hakkındaki kavrayışının değişmesiyle meydana gelmektedir. ${ }^{90}$

33 Jung, Dört Arketip, s. 56.

84 Tüzer, İsmet Özel, s. 255.

85 İsmet Özel, Neyi Kaybettiğini Hatırla, İklim Yayınları, İstanbul 1995, s. 10.

86 B. Bahadır, "Özel Görüșme", 4 Mayıs 2021, Samsun.

87 Victor E. Frankl, Duyulmayan Anlam Çı̆̆llğ l, çev. Selçuk Budak, Öteki Yayınevi, Ankara 1999, s. 111.; Tüzer, Ismet Özel, s. 261.

88 İsmet Özel, $\ddot{U}_{c ̧}$ Zor Mesele, Tiyo Yayınları, İstanbul 2014, s. 239.

89 Özel, Waldo, s. 213.

90 Özel, $\ddot{U}_{c}$ Zor Mesele, 239. 
İşte bütün müsveddelerimi yırttım

işte artık göğsümün kıllarıyla

gövdemin kokusundan buharlaşıyor şiir

işte onlar artık saçların kadar Boşnak

karşılıksız mektuplarım gibi yepyenidir. ${ }^{91}$

Özel'in düşünce sisteminde görülebileceği üzere insan kendi kendisini gerçekleştiren bir varlıktır. ${ }^{92}$ Buna göre uyanan insan, ki mevcudiyet bilincine kavuşmak varoluşsal uyanıştır, ${ }^{93}$ kendi kendinin nedeni ve ne olduğunu kavrama yeteneğini elinde bulundurmaktadır. Dolayısıyla insan için kendi varlığı ile kendi var olmaklığını kavrayan aklını birbirlerinden ayrı iki şey olarak düşünmek mümkündür. Bu durumda Özel'e göre, "insan, hem düşünen hem düşünülendir; hem bilen hem bilinendir yani hem özne hem de nesnedir." 94

\section{Bitimsiz Varoluşsal Kaygı Yolculuğu}

Gidilen yol insanın kim olduğunu ortaya çıkarmaktadır. Dolayısıyla herkes bir ötekine hangi yönü benimsediğine, hangi yoldan gittiğine bakarak kimlik yakıştıracak, takdirle ve de şaşkınlıkla şunu diyecektir: "Vay canına! Demek o yolun yolcusuymuş." ${ }^{95} \mathrm{Bu}$ bağlamda herkese kim olduğunu başkalar1/ herkes söyleyecektir. ${ }^{96}$

Kısmî otobiyografisi olan "Waldo Sen Neden Burada Değilsin" adlı kitabında kendi dönüşümünü ele alan Özel, Müslüman olduğunu deklare ettikten sonra kendisiyle ortak kültürel dili konuşan başka Müslümanlara rast gelmediği için vakıayı aceleye getirmez. Şair, Müslüman olmakla en önemli kazanımını elde ederek içinde bulunduğu "yalnızlıktan" kurtulmuş ve ontolojik varlık sahasında bir emniyete kavuşmuştur. İnsanın bir "durum" olmaktan ziyade bir "süreç" olduğu kabul edildiğinde bahsedilen değişim, hiç de şaşırtıcı değildir. ${ }^{97}$

İnsan kendi kendini seçer, diyerek bireyin kendisi hakkındaki sorumluluğunu hatırlatan Sartre'a göre, istediğimiz "kendilik"i yaratırken herkesin nasıl olması gerektiğini de tasarlamış olmaktayız. Bu bağlamda bahsedilen tasarı herkes için bir

91 Özel, Erbain, s. 151.

92 Özel, Üç Zor Mesele, 116.

3 Özel, Waldo, s. 201.

4 Özel, Üç Zor Mesele, 117.

95 Özel, Waldo, s, 177.

6 Özel, Waldo, s, 212

97 Nusret Yılmaz, “İdeoloji'den Din'e: İsmet Özel’in 70 Sonrası Şiirlerinde Anlam Arayışı", Dil ve Edebiyat Araştırmaları, 18 (2018), s. 62.

Turkish Academic Research Review - Türk Akademik Araştırmalar Dergisi https://dergipark.org.tr/tr/pub/tarr 
değer ve geçerlilik kazanmaktadır. ${ }^{98}$ Ismarlama bir hayata katlanmak yerine arayışa yönelmeyi şart koşan eylemsel tutum, Özel'in "Mataramda Tuzlu Su” adlı şiirinde vurgulanmaktadır:

Uzun yola çıkmaya hüküm giydim.

Beyazların yöresinde nasibim kalmadı

yerlilerin topraklarına karşı şuç işledim

zorbaların arasında tehlikeli bir nifak

uyrukların arasında uygunsuz biriyim

vahşetim

beni baygın meyvaların lezzetinden kopardı

kendime dünyada bir

acı kök tadı seçtim

yakın yerde soluklanacak gölge bana yok

uzun yola çıkmaya hüküm giydim. ${ }^{99}$

Özel'in "Mataramda Tuzlu Su" şiirinde "çıkmaya hüküm giydiği uzun yol" sürekli devam edecek olan bir "yolculuğu" ve dinamizmi belirtmektedir. Zira insanın kendisini keşfetme yolunda yapacağı içsel yolculuğunun sınırları yoktur ve bu yolda sürekli olarak bireysel olmaya doğru bir yöneliş söz konusudur. ${ }^{100} \mathrm{Bu}$ durum, şairin 2003 yılında "Ben sizin durduğunuz yerde tedirgin oldum, başka yere gidiyorum." diyerek Müslümanlara ait herhangi bir süreli yayında yazmama kararından ve bugün hâlen devam etmekte olan çizgisinden anlaşılmaktadır.:

Benim sırrım nefsimi ıslah etmeyişimde sakl1 ${ }^{102}$

$\cdots$

Benden 1srarla nefsimi islah etmemi istediler

Nerede bende o göz

Var mı bende öylesine bir dirim

Nefsimi

Söylesinler kimler hesabına islah edecekmişim ${ }^{103}$

Demek Âdem ahfadından

Savaş bittiği için koynu boşalan

98 Jean-Paul Sartre, Varoluşçuluk, çev. Asım Bezirci, Say Yayınları, İstanbul 2013, s. 101.

99 Özel, Erbain, s.133.

100 Tüzer, İsmet Özel, 280.

101 Tüzer, Issmet Özel, 280.

102 Özel, Of Not Being A Jew, s. 66.

103 Özel, Of Not Being A Jew, s. 70. 
Bir kişi gerekiyormuş o da bendim ${ }^{104}$

$\cdots$

Savaş bitti koynum boş ${ }^{105}$

"Savaş bitti koynum boş" diyen Özel, kendi benlik bilincinin ayırdına varmasının verdiği basınçla hem kendisini hem de modern hayatın yabancılaşma sürecini anlamaya ve anlamlandırmaya çalışmaktadır. Toplumsal bir yabancılaşmanın eleştirisi olarak da okunan bu şiirin anlamsal düzlemi, "görenlerin üstünde iyi duruyor," diye tanımladığı "a posteriori” bir yaşam dizgesinden kurtuluştur. ${ }^{106}$ Diğer bir ifadeyle bu, Müslümanlar arasında mevcut kafa/vaziyet konforundan kadirşinas itaatsizlikle kurtulup herkesleşmemeye direnerek daimi varoluşsal kaygının devamı olarak da okunabilir.

Eric Fromm, doğada kendisini evinde hissetmeyen insanın varoluşsal sıkıntısının çözülmesi gereken ve kaçamadığı en önemli ontolojik sorun olduğunu belirtmektedir. Bu bağlamda insan güçsüzlüğün ve yitikliğin dehşetini yenmeye, kendisini dünyaya bağlayacak ve kendisini yuvasında hissetmesini sağlayacak yeni biçimler bulmaya mecbur kalmaktadır. ${ }^{107}$

Uzak nedir?

Kendinin bile ücrasında benim için

Gidecek yer ne kadar uzak olabilir ${ }^{108}$

"Kendisinin bile ücrasında yaşayan" şairin insanın değerler bakımından yoksullaşması şeklinde tanımladığı "yabancılaşma"; bireyin parçalanmasını ve aslî değerlerini kaybetmesini ifade etmektedir. Bu bağlamda, Özel'e göre insanı kendi değerlerinden ve varlığından uzaklaştıran yabancılaşma düzlemi, alım-satıma konu olmayan hiçbir nesnenin kalmamasına ve sistemin akıl erdirilmeyen bir mekanizmayla üretim ve tüketim orduları, tapınakları ve bankalarıyla dinden/özgün değerlerinden uzaklaşmış şekliyle insanlara tanrılık etmektedir. ${ }^{109}$ Dizelerden takip edilirse şair bu durumu, "plastik sürahilerin tanrısı" betimlemesiyle şok etkisiyle okuruna duyurmak ve kendi şahsında onları "herkesleşme" konusunda uyarmak istemektedir:

Ben ne büyük bir dalgınlıkla bakmış olmalıyım ki hayata

\footnotetext{
104 Özel, Of Not Being A Jew, s. 80.

105 Özel, Of Not Being A Jew, s. 81.

106 Y1lmaz, "Mataramda Tuzlu Su", s.139.

107 Eric Fromm, İnsanda Yıkıcılığın Kökenleri, çev. Şükrü Alpagut, Payel Yayınlar, İstanbul, 2011, s.283-285.

108 Özel, Erbain, s. 223.

109 Tabip Gülbay, Ismet Özel'de Yabancılaşma, Artuklu Yayınları, Mardin 2015., s.74-78.
}

Turkish Academic Research Review - Türk Akademik Araştırmalar Dergisi 
görmedim orda çinko damlar ve plastik sürahilerin tanrısını

yerimi yadırgadım

yerim olmadı zaten kendi mezarımdan başka

çılgının biri sanılmaktan sakınmaya vaktim olmadı. ${ }^{110}$

Yukarıdaki dizeler bağlamında Özel, kendilik bilincine ulaşamamış ve "neler

olup bittiğini hiçbir ayetten hiçbir vakit anlamayacak" şehrin insanına/topluma/herkese karşı gerçekçi olma inadındadır. Mümkün olanı değil imkânsızı istemektedir. ${ }^{111}$ Zira o, güncel dünyanın verdiklerinin ona yaramadığını söylemekte ve çocukluğundan beri görülen, görünen ve gösterilen dünyaya alışmamak inadında olduğunu ifade etmektedir.

\section{Sonuç}

Bireyin kendisini düşünüp dünyadaki varoluşunun mahiyeti ile ilgilenmeye başlamasıyla ortaya çıkan "varoluşsal kaygı” problemi Özel'in şiirleri üzerinden ele alındığında, Kierkegaard ve Heidegger gibi bazı filozofların belirledikleri varoluş evrelerine benzer dört aşamanın Özel şiirinde de görüldüğü anlaşılmaktadır. Buna göre söz konusu evrelerden ilki insanın kendi mahiyeti ile ilgilenmeden önceki toplumsallaşmasından kaynaklı olarak "ben"i ile içerisinde bulunduğu dünyaya konumlanamamasıdır. Söz konusu aşamada kişi, henüz birey ve kendi olamamış, içinde bulunduğu toplum ile özdeşleşmiştir. Bu aşamada kendiliği üzerine tefekkür eden birey, Özel düşüncesinde, “Dur bakalım bir de biz gözden geçirelim” ayıklığı ile sunulana karşı şüpheci ve meraklı bir duruş sergilemektedir. Çünkü bu, hayatın içinde hem "mecbur bırakılmışlık"ların fark edilmesi hem de "insanlığımızın" zuhur etmesiyle yakından ilgilidir.

Bahsedilen evrelerden ikincisi, dünyaya konumlanamama ile zuhur eden huzursuzlukla beraber kendiliğe dair farkındalığın oluşması sonucunda "herkesleşmeme"dir. Bu aşamada kişi, birey olarak kendi varlığının farkına varmasıyla sürü ya da herkesin kendisine yüklediği sosyal kimliğinden sıyrılma çabasına girmektedir. Söz konusu durum ile kendisini hissettiren "yalnızlık," var oluşunu sorgulayan her insanda olduğu gibi Özel örneğinde de ilk olarak herkes içinde olmasına rağmen "sahicilik" arayışı sebebiyle kendine sunulanın reddiyle birlikte ortaya çıkmaktadır. Bu bağlamda kişi, Özel düşüncesine göre, "herkesleşmeme" sonucunda kendi varoluşuyla ilgili kararları alma sorumluluğundan kaçarak

110 Özel, Erbain, s. 203.

111 Özel, Waldo, s. 143. 
belirlenmiş olmanın kendilerine sağlamış olduğu rahatlığı yaşayan "Sessiz Yığınların Gölgesi"nden uzak durmalıdır.

Söz konusu varoluşsal evrelerden üçüncüsü; herkesleşmemenin getirisi olarak ortaya çıkan yalnızlık sonucunda yeniden doğuş ile kazanılan kendilik bilincidir. Bu üçüncü aşamada birey, artık "başlangıçtaki insan" değildir. Özel'e göre bu aşamada insan, her şeyden önce kendisini tanımlamakta ve kendi hakkındaki kavrayışııı değiştirmektedir. Başka bir deyişle kişi, kendi kendisini gerçekleştirmektedir.

Bitimsiz varoluşsal kaygı yolculuğu olarak isimlendirilen dördüncü evre ise, kendilik bilincine ulaşmış bireyin varoluşsal şüphesinin bitmeyip devam edeceğini göstermiştir. Özel'in Müslüman olup ontolojik varlık sahasında güvenliğini sağlamasından sonra da kendisini keşfetme yolunda içsel yolculuğunun halen devam ettiği görülmektedir. Bu bağlamda denilebilir ki kendilik bilincine ulaşmış birey, her gün güncelliğini yenileyerek devam eden toplumsallığa ve bu durumun getirisi olan "ısmarlama hayata" karşı kendi arayışııı devam ettirmek zorundadır. Diri kalmak, Özel'in de dediği gibi, kendiliğin içinde arayışa devam etmek ile mümkündür: çünkü insan aradıkça diridir, aradıkça anlamaktadır.

\section{Kaynakça}

Ali Algül, Popüler Kültür ve Popüler Edebiyat, Europan Journal of Educational \& Social Sciences, Volume 4, Issue 2, October 2019, s. 142-153.

Aristoteles, Metafizik, çev. Ahmet Arslan, Divan Kitap, İstanbul 2019.

Bahadır, B., "Özel Görüşme”, 4 Mayıs 2021, Samsun.

Baudrillard, J., Sessiz Yı̆̆ınların Gölgesinde, çev. Oğuz Adanır, Doğu-Batı Yayınları, Ankara 2003.

Durant, W., Felsefenin Öyküsü, çev. Ender Gürol, İzdüşüm Yayınları, İstanbul 1997.

Fromm, E., İnsanda Ylkıcıll̆ğn Kökenleri, çev. Şükrü Alpagut, Payel Yayınlar, İstanbul, 2011.

Gasset, O., Insan ve Herkes, çev. Neyire Gül Eşik, Metis Yayınları, İstanbul 1995.

Göküş, Ş., "II. Meşrutiyet Dönemi İslamcı Çizgideki Süreli Yayınlarda Aile ve Çocuk Eğitimi”, Artuklu Akademi, 7/1 (2020), ss.109-118.

Göküş, Ş., Koçoğlu, B., Atay, R., “Aliya İzzetbegoviç'e Göre Bireyin ve Toplumun Eğitiminde Kadının Rolü,” Anmak, Anlamak ve Aşmak Bağlamında Aliya İzzetbegoviç, ed. Çetin, Yalçın, Nobel Akademik Yay., Ankara, 2021.

Turkish Academic Research Review - Türk Akademik Araştırmalar Dergisi https://dergipark.org.tr/tr/pub/tarr 
1544 Daimî Varoluşsal Kaygı: İsmet Özel Şiiri Örneği

Gözal, Ö., "Heidegger'de 'Herkes' Sorunsalı" Felsefe ve Sosyal Bilimler Dergisi, 30 (2020), s. 17-36.

Gülbay, T., Ísmet Özel'de Yabancılaşma, Artuklu Yayınları. Mardin 2015.

Heidegger, M., Varlık ve Zaman, çev. A. Yardımlı, İdea Yayınları, İstanbul, 2004.

Jung, C. G., Dört Arketip, çev. Zehra Aksu Yılmazer, Metis Yayınları, İstanbul 2003.

Kant, I., Pratik Aklın Eleştirisi, çev. Gertrude Durusoy, Türkiye Felese Kurumu, Ankara 1999.

Karslı, B., Farklılık ve Birlikte Yaşama: Göksun İlçesi Örnekliğinde Din ve Sosyal Bütünleşme, İlahiyat Yayınları, Ankara 2016.

Özel, İ., Erbain- Kırk Yllın Şiirleri, Tiyo Yayınları, İstanbul 2013.

........ Of Not Being A Jew, Şule Yayınları, İstanbul 2005.

. Waldo Sen Neden Burada Değilsin, Tiyo Yayınları, İstanbul 2018.

........ Çatllycak Kadar Aşkî, Adam Yayıncılık, İstanbul 2003. Bir Yusuf Masalı, Şûle Yayınları, İstanbul 2004.

.........Hayatın Mânâsı versus Mânâlı Bir Hayat, haz., Ercan Yıldırım, Şule Yay., İstanbul, 2010.

Saint-Exupéry, A., Küçük Prens, çev. Ayberk Erkay, Lotus Yayınevi, Ankara 2005.

Sartre, J. P., Varoluşçuluk, çev. Asım Bezirci, Say Yayınları, İstanbul 2013.

Shayegan, D., Yaralı Bilinç- Geleneksel Toplumlarda Kültürel Şizofreni, çev. Haldun Bayrı, Metis Yayınları, İstanbul 1991.

TDK., (Erişim Tarihi: 10 Ekim.2021)

Tüzer, İ., İsmet Özel-Şiire Damıtılmış Hayat, Dergâh Yayınları, İstanbul 2012.

Yılmaz, N., “İdeoloji'den Din'e: İsmet Özel'in 70 Sonrası Şiirlerinde Anlam Arayışı", Dil ve Edebiyat Araştırmaları, 18 (2018), s. 57-80.

“İsmet Özel'in 'Mataramda Tuzlu Su' Adlı Şiirinde Özne’nin İnşası”,

Kesit Akademi Dergisi, 15 (2018), s, 130-140.

Turkish Academic Research Review - Türk Akademik Araştırmalar Dergisi 